\title{
INTRODUCING ENGINEERING TO GIRL SCOUTS
}

\author{
Karen E. Schmahl \\ Miami University
}

\begin{abstract}
One approach to attracting more young women to study engineering disciplines is to spark their interest in engineering early in their education (K-12). Several opportunities are available to introduce young women to engineering disciplines through alliance with local Girl Scouts of the USA councils. This paper describes the efforts of one such alliance and approach to introducing young women to engineering and technology.

The Manufacturing Engineering Department at the School of Applied Science, Miami University and the Great Rivers Girl Scout Council in the Cincinnati, Ohio, area combined efforts to develop a program to introduce engineering to Girl Scout members. A team of senior engineering students, with the author and Girl Scout Council guidance, have developed the framework for a workshop focusing on engineering design activities and teamwork as well as technology applications. Activities were targeted to sixth, seventh and eighth graders and enable participants to earn Girl Scout recognitions (badges) related to science and technology.
\end{abstract}

\section{BACKGROUND}

Miami University in Oxford, Ohio, has a small undergraduate engineering program with approximately 160 students in Manufacturing Engineering (ABET accredited) and another 90 students in the interdisciplinary Engineering Management program with a technical specialty in Manufacturing Engineering. All senior engineering students are required to take a two semester (two credit hours each semester with four credit hours of design) capstone course. In the first semester the students define and research an engineering or manufacturing related problem, develop and evaluate solutions and present their chosen designs. The second semester focuses on implementation of solutions and assessment of project outcomes. These senior design projects are often coordinated with industry or conducted within the university laboratories.

The Manufacturing Engineering Department is also very service oriented and has conducted numerous senior design projects for the benefit of non-profit organizations. The author's involvement in the local Girl Scouting program recently led to two senior design projects. The first the involved the design and construction of a foot bridge at a local Girl Scout camp. The second project, less traditional in nature, was to design a program to introduce Girl Scouts to engineering.

\section{WHY INTRODUCE ENGINEERING TO GIRL SCOUTS?}

The underlying reason for proposing the Girl Scout Engineering project was to attract more young women to study engineering disciplines by sparking their interest early in their education. Girl Scouts of the 
USA is an organization devoted to the growth and development of girls and young women from kindergarten through twelfth grade. The Girl Scouting organization provides an audience of young women who are very receptive to new endeavors.

There are numerous compelling arguments for establishing programs to encouraging more women to seek careers in engineering. An economic argument can be made based on the projected need for more engineers. In addition, persuasive arguments can be made relative to equity and diversity. ${ }^{1}$ The US Department of Labor predicts a 32\% increase in the projected number of engineers from 1986 to the year 2000 because of high-technology industry growth and increasing use of high-technology goods and services. ${ }^{2}$ In 1994 , the percentage of engineering degrees awarded to women was 16.6?403. With women being under-represented in engineering fields, the recruitment of young women into engineering is looked upon as necessary to meet projected needs. This economic argument is gaining increasing attention. The simple argument of equitable treatment and equal opportunities for all citizens has in the past decades opened many doors for women and minorities into education, the workplace and in social environments. From a diversity perspective, these new entrants bring fresh ideas and new perspectives to the workforce. ${ }^{1}$ This contributes to society resilience and adaptability, which are particularly important with rapid advancements in technology.

National leadership of the Girl Scouts of the USA has shown enthusiasm for promoting the understanding that women can and do excel in different careers and endeavors. Recognition of the need to help girls view science, math and technology careers as valid and desirable led to a 1987 publication in the Girl Scout Contemporary Issues Series entitled "Into the World of Today and Tomorrow: Leading Girls to Mathematics, Science, and Technology". Since that time, the handbooks for Brownie and Junior level Girl Scouts, grades 13 and 4-6, respectively, as well as the Girl Scout Badges and Signs book have been revised to include more activities related to science and technology. ${ }^{5,6,7}$ Plans are to update the Cadette (grades 7-9) and Senior (grades 10-12) materials to be more reflective of opportunities in technology.

The national Girl Scout leadership also recognized that Girl Scout leaders may be somewhat science shy. The National Science Partnership (NSP) for Girl Scouts and Science Museums was formed as a nation-wide collaboration between science museums and Girl Scout Councils with primary funding provided by the National Science Foundation. According to an NSP brochure, "Its goal is to make science fun and exciting for girls as they earn Girl Scout recognitions by supporting Girl Scout leaders through training and hands-on science kits." Science activity kits were developed, each fulfilling the requirements of one science-related Girl Scout recognition. The kits are then available to Girl Scout leaders who receive training through the NSP.

The NSP kits and reference material do an excellent job of preparing leaders to help girls learn about science and earn the science-related badges. Unfortunately, none of the science badges included in the program even mentions the word "engineering". Other than a listing of the addresses of most of the major engineering professional societies found in the Contemporary Issues publication, the national Girl Scout headquarters does not provide orchestrated direction for pursuing interests in this area. A representative from the national Girl Scout headquarters indicated that collaborations are sometimes made by local Girl Scout councils with organizations, such as the Society of Women Engineers, to provide expertise in engineering or applied sciences.

The Great Rivers Girl Scout Council in the Cincinnati, Ohio area showed considerable enthusiasm for working with Miami University to developing a program to introduce engineering to Girl Scout members. The senior engineering students set as a goal to develop a program with the Great Rivers Council which could serve as a model for other universities and Girl Scout Councils to use. 


\section{TARGET AUDIENCE}

The senior engineering students worked with the representatives of the Great Rivers council and performed preliminary literature research to determine an appropriate age group for a program on engineering. Then the Girl Scout recognitions/badges were reviewed for engineering and technology related activities.

Sixth, seventh and eight graders were selected as the most appropriate age group for introduction to engineering. As pointed out by McIlwee and Robinson, ${ }^{g}$ if programs or individuals are to be effective in guiding more women into engineering, they must be present at the junior high level and even in the elementary schools. Reasoning for this is that crucial preparatory math and science courses must be taken throughout secondary education. The 1990 survey by the American Association of University Women indicated that between the ages of nine and fifteen, girls experience a significant drop in self-esteem, particularly related to math and science. 10 Encouragement to study math and sciences appears to be critical in the early years of this developmental stage. An additional reason to target this age group is to make the students aware of engineering as a viable career opportunity, dispelling any perception of engineering as an exclusive male domain. Research has shown that in countries where secondary school girls have a reasonable expectation that desirable occupations will be open to them, they perform better at math than do girls in countries with rigid sex-typing of jobs. ${ }^{11}$

After determining the age range which would be suitable for an engineering program, the associated Girl Scout badges in the areas of engineering and technology were identified. Sixth grade students are generally in Junior level Girl Scout troops with seventh and eighth graders in Cadettes. At the Junior level, two recognitions contained considerable aspects of engineering and technology. In the "Science in Action" badge the Juniors could choose from activities such as researching the different types of engineers, designing a transportation system, visiting a factory and building a suspension bridge. The "Discovering Technology" badge included activities from discovering how pulleys are used to finding out about advanced technologies such as voice recognition, virtual reality, lasers and robots. ${ }^{6}$ At the Cadette level, there were no appropriate recognitions in the areas of technology or engineering. (Plans are to have an Interest Project/Patch in the revised Cadette and Senior Girl Scout material due out in 1997.)

Although the Cadette level did not have an appropriate badge as yet in the engineering area, the senior design team elected to continue to target the program to them as well as the sixth grade Juniors. The elements of the Junior badges were, however, kept in mind in designing a program.

\section{PROGRAM IDEAS}

With the problem more clearly refined (verification of need and identification of target age group) and background research completed on the Girl Scout organization, the senior design team commenced to brainstorm solutions for addressing the needs. Selection of a high-level format quickly focused on two ideas.

The first approach involved development of kits and informational material, similar to those in the NSP program, which could be used during troop meetings. A preliminary visit to a troop highlighted several problems with this approach. To present a program, even with a kit and possibly a video, a person should be well versed in engineering design principles. Such a program would also be well served with a female engineering role model. Very few Girl Scout leaders meet these criteria so an outside consultant would need to be available. The senior engineering students felt that even if they could write informational material to help the leaders, such a troop-based presentation lacked the "dazzle" of real equipment and an engineering environment. Logistical problems of distribution of kits was also a drawback of this format. 
The second approach involved the development of an engineering workshop for Girl Scouts to be held at the university. The primary advantages of this approach are the availability of resources such as the engineering and computer laboratories as well as knowledgeable personnel and role models (engineering faculty and students). The senior design students decided to develop a framework for an engineering workshop for Girl Scouts which could be used as a model by other engineering schools and Girl Scout councils. A pilot workshop would be conducted at the Miami University campus.

Once the overall format was established, efforts focused on developing the content of the workshop. The students felt strongly that the scope of the program should go beyond demonstrations of technology. To encourage more young women to consider engineering as a career, traditional (wrong) images of engineering need to be revised. 12 Engineering must therefore be presented as creative rather than factual/non-negotiable and people-oriented rather than only phenomena oriented. The girls should have the opportunity to learn and apply engineering design and teamwork concepts along with the technology demonstrations. With this premise, a framework for the workshop was developed.

\section{THE WORKSHOP FRAMEWORK}

The workshop elements as described below was developed to provide Girl Scouts with an introduction to engineering and an opportunity to earn technology related badges. The program is designed to be run in a single day format and may be tailored to fit various university resources.

I. Introduction to Technology and Engineering Design - Participants are welcomed to the program and given an overview of the day's activities. They are then broken into small groups to discuss the logs of technology they used in the previous week (which they were instructed to bring with them). They perform the activity "What can you do without'?" as described in the Junior Girl Scout Handbook. Program leaders reassemble the participants and describe what brought these technologies to market - the engineering design process.

II. Simple Machines - Design Exercise I - Participants move between stations to experiment with levers, screws, pulleys, inclined planes, wedges and the wheel and axle. They are then formed into groups to use the engineering design process to create a mechanism which solves an assigned problem.

III. Tour of Labs and Lab Exercise - The girls are then provided with a tour of the Computer Integrated Manufacturing and Paper Making Laboratories. Discussion focuses on use of science and technology in manufacturing. They either perform a robotics exercise or make paper.

IV. Structures - Design Exercise II - Participants are given a scenario (build bridge across creek at day camp), then led through the design process to build a bridge. The importance of identification of customer needs as well as physical, environmental and cost constraints is highlighted. The students are then placed into teams, given a set of assorted material and asked to build a model bridge.

V. Panel Discussion - Engineering students and professors describe the different types of engineering and why they chose engineering as a profession. Girls are given the opportunity to ask questions about requirements to get an engineering degree and on college life.

VI. Computer Lab Exercises - A brief lecture on computer networks is given, then the girls are directed in surfing the Internet. The participants then send an E-mail message to the program director telling her what they liked best and least about their introduction to engineering. 
The application of workshop activities towards Junior Girl Scout badge requirements is provided in table below.

\section{Introducing Girl Scouts to Engineering}

Program Elements and Their Relationship to Girl Scout Recognitions

\begin{tabular}{|c|c|c|}
\hline \multirow[t]{2}{*}{ Program Elements } & \multicolumn{2}{|c|}{ Junior Girl Scout Badge Requirements } \\
\hline & Discovering Technology & Science in Action \\
\hline $\begin{array}{l}\text { Introduction - Engineering Design } \\
\text { and Technology }\end{array}$ & $\begin{array}{l}\text { - Discover how often you rely on } \\
\text { technology. Keep a log for a week listing } \\
\text { how and when you use technology (done } \\
\text { prior to attendance). Do "What can you } \\
\text { do without" activity. }\end{array}$ & \\
\hline $\begin{array}{l}\text { Simple Machines - } \\
\text { Team Design Exercise I }\end{array}$ & $\begin{array}{l}\text { - Discover pulley power. Send a message } \\
\text { or lift an object using pulleys. } \\
\text { - Do the Science Challenge "How do you } \\
\text { make a book move across a bare floor } \\
\text { moving one finger? }\end{array}$ & $\begin{array}{l}\text { - Design something using science and } \\
\text { technology that you would like to have in } \\
\text { your community in the near future to } \\
\text { improve the quality of life. }\end{array}$ \\
\hline $\begin{array}{l}\text { Tour of CIM and Paper Laboratories } \\
\text { Robotics Lab Exercises or } \\
\text { Paper Making }\end{array}$ & $\begin{array}{l}\text { - Discover how technology is shaping the } \\
\text { future. Find out about at least two of the } \\
\text { following: voice recognition, virtual } \\
\text { reality, lasers, telecommunications, } \\
\text { robotics. If possible use or view one of } \\
\text { these technologies. }\end{array}$ & $\begin{array}{l}\text { - Visit a factory in your community. Find } \\
\text { out how science is used in manufacturing. }\end{array}$ \\
\hline $\begin{array}{l}\text { Structures - } \\
\text { Team Design Exercise II }\end{array}$ & & $\begin{array}{l}\text { - Build a model of a suspension bridge, } \\
\text { using rope, twine, boxes, chairs or other } \\
\text { materials. Share it with your troop or } \\
\text { group. }\end{array}$ \\
\hline Panel Discussion & & $\begin{array}{l}\text { - Ask people what kinds of engineers } \\
\text { there are until you find at least five } \\
\text { different kinds. Find out what at least } \\
\text { three kinds of engineers do in their job. }\end{array}$ \\
\hline Computer Lab Exercises & $\begin{array}{l}\text { - Discover computer networks. } \\
\text { Investigate how they work and what they } \\
\text { cost. Send a message on E-Mail } \\
\text { - Discover a leisure time activity that uses } \\
\text { technology. (Surf the Internet. Create a } \\
\text { home page.) }\end{array}$ & \\
\hline
\end{tabular}

\section{FUTURE WORK}

With the framework established, the detail planning has begun for the pilot presentation of the Girl Scout Introduction to Engineering program to be held in April of 1996. The senior engineering students will be coordinating all the aspects of the workshop. They have enlisted the members of the Miami University chapter of the Society of Women Engineers to provide assistance during the day's activities.

The Great Rivers Girl Scout Council has provided guidance in the development of this program. In the months prior to the program, the Council office will be handling all publicity and registration aspects. Because this program is being offered as a troop activity (multiple troops participate rather than individual girls) adult leaders attending will provide adult supervision of the girls during the day as well as make travel arrangements. The Council office will handle any follow-up support as deemed appropriate, such as providing additional information on resources to leaders. 
"In Girl Scouting the girls are the focus in an environment that aims to provide them with selfconfidence and skills. In addition, in Girl Scouting girls routinely see women in positions of authority. This helps them understand that women can and do excel in leadership positions as well as in different careers and endeavors."

The above quote from the Junior Girl Scout Leaders Manual, illustrates why a programs such as the Girl Scout Introduction to Engineering are important to the Girl Scouting organization. Alliance between the Miami University School of Applied Science and the Great Rivers Girl Scout Council has provided a winning situation for all concerned. The Girl Scout Introduction to Engineering program enables the Great Rivers Council to further embrace the goals of Girl Scouting.

Miami University senior design students in engineering have had the opportunity to utilize their engineering and organizational skills to design and implement a very worthwhile program. The Girl Scouts Introduction to Engineering program will be documented and turned over to the local Society of Women Engineets chapter to be offered on an annual basis.

A model has been offered in the hopes that other engineering schools will follow and improve upon the program when working with their own area Girl Scout Councils. Hopefully then, greater numbers of young women will be encouraged to pursue engineering as a career, helping to meet the projected need for engineers.

\section{ACKNOWLEDGMENTS}

The author would like to acknowledge the efforts of the senior design students in the Manufacturing Engineering Department of Miami University and the representative from the Great Rivers Girl Scout Council for their contributions on this project. Engineering Management majors, Jeffrey Jorgensen and Jeffrey Wooledge and Manufacturing Engineering major Elizabeth Bennett have devoted many hours to developing and presenting the workshop. The guidance and assistance of Susan L. Osborn, Program/Property Manager at the Great Rivers Girl Scout Council was greatly appreciated.

\section{R E F E R E N C E S}

${ }^{1}$ Wilson, Linda S. "The Benefits of Diversity in the Engineering and Science Work Force" in Science and Engineering Programs: On Target for Women?, edited by Matyas, Marsha Lakes and Dix, Linda Skidmore, National Academy Press, Washington DC, 1992,

${ }^{2}$ US Department of Labor, Bureau of Labor Statistics Outlook 2000 (Bulletin 2302), Washington DC: US Government Printing Office 1990.

${ }^{3}$ Engineering Workforce Commission (New York and Washington: American Association of Engineering Societies, 1979-1995)

${ }^{4}$ Girl Scout Contemporary Issues Series, "Into the World of Today and Tomorrow: Leading Girls to Mathematics, Science, and Technology”. Girl Scouts of the USA, New York, New York, 1987. 
${ }^{5}$ Brownie Girl Scout Handbook, Girl Scouts of the USA, New York, New York, 1993.

${ }^{6}$ The Guide for Junior Girl Scout Leaders, Girl Scouts of the USA, New York, New York, 1994.

'Girl Scout Badges and Signs. Girl Scouts of the USA, New York, New York, 1990.

${ }^{8}$ National Science Partnership For Girl Scouts and Science Museums, brochure available from Chris Bergerson, NSP Manager, Girl Scouts of the U. S. A., New York, New York.

${ }^{9}$ Mcllwee, Judith S., and Robinson, J. Gregg, Women in Engineering: Gender. Power and Workplace Culture, State University of New York Press, Albany, NY, 1992

${ }^{10}$ American Association of University Women, Shortchanging Girls, Shortchanging America, Greeberg-Lake Analysis Group, Washington, DC, 1990.

${ }^{11}$ Jones, Deborah Perkins and Baker, David P., "Opportunity and Performance: A Sociological Explanation for Gender Differences in Academic Mathematics", in Education and Gender Equity, edited by Julia Wrigley, The Falmer Press, Washington, DC, 1992.

${ }^{12}$ Byrne, Eileen M., Women and Science: The Snark Syndrome, The Falmer Press, Washington, DC, 1993.

KAREN E. SCHMAHL, Ph. D., P. E., is an Assistant Professor in the Department of Manufacturing Engineering at Miami University, Oxford, Ohio. She received degress in industrial engineering from the University of Cincinnati (Ph. D.) and Texas A\&M University. (B. S. and M.E.). Industrial experience includes positions held at General Electric Aircraft Engine, E-Systems and Rockwell International. 